\title{
Response of broilers to digestible sulfur amino acids and threonine intake: Maximum economic return
}

\author{
Respuesta de pollos de engorde a la ingesta de aminoácidos azufrados y treonina digestibles: máximo \\ retorno económico \\ Resposta de frangos de corte ao consumo de aminoácidos sulfurados e treonina digestíveis: máximo \\ retorno econômico
}

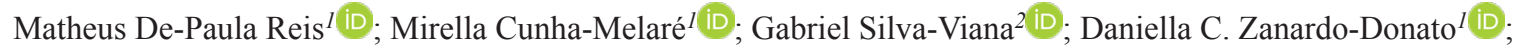 \\ Nilva Kazue-Sakomura ${ }^{1 *}$ (D).
}

\begin{abstract}
${ }^{1}$ Departamento de Zootecnia, Faculdade de Ciências Agrárias e Veterinárias (FCAV), Universidade Estadual Paulista (Unesp), 14884-900, Jaboticabal, São Paulo, Brasil.

${ }^{2}$ Natural Resources Institute Finland (Luke), Jokioinen, Finland.
\end{abstract}

\section{To cite this article:}

Reis MDP, Cunha-Melaré M, Silva-Viana G, Zanardo-Donato DC, Kazue-Sakomura N. Response of broilers to digestible sulfur amino acids and threonine intake: maximum economic return. Rev Colomb Cienc Pecu 2020; 33(4): $239-251$. DOI: https://doi.org/10.17533/udea.rccp.v33n4a04

\section{Abstract}

Background: The determination of amino acid supplements for broiler chicken requirements based on performance does not always reflect maximum profitability. Objective: To estimate the optimal levels of digestible threonine (Thr) and sulfur amino acids (SAA) in diets for broilers based on an economic analysis. Methods: Two dose-response assays were conducted, and each assay was divided into three phases: initial (1-14 days), grower (15-28 days), and finisher (29-42 days). Five hundred and sixty male Cobb $500^{\circledR}$ broilers were randomly distributed to seven treatments with increasing levels of the amino acid (SAA or Thr), with four replicates and 20 birds each. Bodyweight gain (BWG) and feed intake (FI) were used to fit a segmented model. Gross income (GI), total feed costs (TFC) and gross margin (GM) were calculated based on local values. Results: Increasing levels of amino acid elicited a response in BWG and FI for all evaluated phases. The estimates for maximum profit based on GI and TFC were 223, 504, and $975 \mathrm{mg} \mathrm{SAA} / \mathrm{bird} / \mathrm{d}$, and 236, 696, and 1,042 $\mathrm{mg} \mathrm{Thr/bird/d} \mathrm{in} \mathrm{starter,} \mathrm{grower} \mathrm{and}$ finisher phases, respectively. Conclusion: Varying the AA prices affected only slightly the economic optimal intake of Thr and sulfur amino acids. Despite market fluctuations, the economic approach presented in this study demonstrates to be a helpful tool to choose the ideal inclusion level of amino acids in the feed.

Keywords: amino acid supplementation; dose-response; economic return; feed cost; gross margin; growth performance; poultry; segmented model.

Received: November 24, 2017; accepted: April 20, 2020

*Corresponding author. Rod. Professor Paulo Donato Castellane, km 5, Rural, Jaboticabal, São Paulo, Brasil, CEP: $14884-900$. Tel.: +55 16 3209-7503. E-mail: sakomura@,fcav.unesp.br 


\section{Resumen}

Antecedentes: La determinación de la suplementación de aminoácidos en las dietas de pollos de engorde, basados solamente en el desempeño productivo no siempre refleja la máxima rentabilidad. Objetivo: Estimar los niveles óptimos de treonina (Thr) y aminoácidos azufrados (SAA) en dietas para pollos de engorde basados en un análisis económico. Métodos: Se realizaron dos ensayos tipo dosis-respuesta divididos en tres fases cada uno: inicio (1-14 días), crecimiento (15-28 días) y finalización (29-42 días). Quinientos sesenta pollos de engorde machos Cobb $500^{\circledR}$ se distribuyeron aleatoriamente en siete tratamientos con niveles crecientes de aminoácidos (SAA o Thr) y cuatro repeticiones de 20 aves cada uno. La ganancia de peso (BWG) y el consumo de alimento (FI) fueron utilizados para ajustar un modelo segmentado. El ingreso bruto (GI), costo total de la ración (TFC) y el margen bruto (GM) se calcularon tomando como referencia valores locales. Resultados: Los niveles crecientes de aminoácidos influyeron en la respuesta de BWG y FI en todas las fases evaluadas. Los estimados para maximizar la rentabilidad según GI y TFC fueron 223, 504 y $975 \mathrm{mg} \mathrm{SAA} /$ ave/día, y 236, 696 y 1,042 mg Thr/ave/día para las fases de inicio, crecimiento y finalización, respectivamente. Conclusión: La variación de los precios de los AA tuvo solo un ligero efecto sobre el consumo óptimo de Thr y aminoácidos azufrados. A pesar de las fluctuaciones del mercado, el enfoque económico aquí expuesto demuestra ser una herramienta útil para la elección del nivel ideal de inclusión de aminoácidos en la formulación.

Palabras clave: avicultura; costo de alimentación; dosis-respuesta; margen bruto; modelo segmentado; rendimiento de crecimiento; retorno económico; suplementación de aminoácidos.

\section{Resumo}

Antecedentes: A determinação da suplementação de aminoácidos em frangos de corte baseados somente no desempenho produtivo nem sempre reflete a rentabilidade máxima. Objetivo: Estimar os níveis ótimos de treonina (Thr) e aminoácidos sulfurados (SAA) em dietas para frangos de corte com base em uma análise econômica. Métodos: Foram realizados dois ensaios dose-resposta, divididos em três fases cada: inicial (1-14 dias), crescimento (15-28 dias) e final (29-42 dias). Quinhentos e sessenta frangos de corte machos Cobb $500^{\circledR}$ foram distribuídos aleatoriamente em sete tratamentos, representados por níveis crescentes de aminoácidos (SAA ou Thr), com quatro repetições de 20 aves cada. O ganho de peso (BWG) e o consumo de ração (FI) foram utilizados para ajustar um modelo segmentado. A receita bruta (GI), os custos totais de alimentação (TFC) e a margem bruta (GM) foram calculados com base nos custos locais. Resultados: Os níveis dos aminoácidos influenciaram as respostas de BWG e FI para todas as fases avaliadas. A estimativa para máximo lucro com base em GI e TFC para os ensaios com SAA foram 223, 504 e $975 \mathrm{mg} / \mathrm{ave} / \mathrm{d}$; para $\mathrm{Thr}$ foram 236, 696 e 1,042 mg/ave/d para as fases inicial, crescimento e final, respectivamente. Conclusão: A variação dos preços dos AA teve pouca influência sobre a ingestão econômica dos aminoácidos sulfurados e da Thr. Apesar do dinamismo de mercado, a abordagem econômica apresentada neste estudo demonstra ser uma ferramenta útil para a escolha do nível de inclusão ideal do aminoácido na ração.

Palavras-chave: avicultura; custo de alimentação; desempenho de crescimento; dose-resposta; margem bruta; modelo segmentado; retorno econômico; suplementação de aminoácido. 


\section{Introduction}

Over the years, nutritionists have studied several ways to determine the ideal dietary supply of essential amino acids to optimize poultry performance. However, considering only performance objectives without taking into account economic factors may not reflect maximum profitability, since optimizing performance is not always viable (Pack et al., 2003). An economic approach to determine amino acid supply by minimizing feeding costs and maximizing revenues was proposed by Pack et al. (2003). However, the minimum cost approach is only acceptable from an economic standpoint, when the revenue is held constant (Vedenov and Pesti, 2010; Pesti and Vedenov, 2011). The revenue is constant when a segmented model, such as the quadratic-plateau model, is used. In this model, once the plateau is reached, any increase in amino acid levels is assumed not to have any additional response effect (Hauschild et al., 2010).

Modern broiler diets are formulated with reduced crude protein and are often supplemented with crystalline SAA, Lys, and Thr to meet muscle accretion and feather synthesis requirements. In a previous study (Siqueira et al., 2011), the optimal economic levels of dietary Lys for broilers were estimated using the exponential equations described by Pack et al. (2003). Since maximum economic return is ideal for poultry production, determining SAA and Thr levels could represent an important step forward to optimizing production cost.

Imbalances in dietary amino acids supply may decrease their efficiency for utilization and consequently impair bird growth potential (Kidd, 2000; Kidd, et al., 2004) compromising economic return. In this context, establishing amino acid intake also requires an economic evaluation to determine which amount of the amino acid should be supplied in the feed to maximize economic return. Some researchers have reported dietary levels of SAA (Pack and Schutte, 1995) and Thr (Kidd et al., 1999) using economic evaluations, but the exponential models used in their economic approach may have limitations (Pesti and Vedenov, 2011).

In the present study we aimed to estimate the optimal SAA and Thr levels in broiler diets using segmented models fitted to performance data obtained in dose-response assays and based on economic analysis of gross margin over feed costs.

\section{Materials and methods}

\section{Ethical considerations}

The Ethics Committee on Animal Use of Faculdade de Ciências Agrárias e Veterinárias, Unesp, campus in Jaboticabal, São Paulo, Brazil, approved all the experimental procedures adopted in this study (protocol No. 007125-08).

\section{Experimental design}

Two dose-response assays were conducted to obtain the response of broilers submitted to different levels of digestible SAA and Thr. The trials were conducted at the Poultry Science Laboratory of Faculdade de Ciências Agrárias e Veterinárias, Unesp, campus in Jaboticabal, São Paulo, Brazil. For both amino acids, the study was divided into initial (1-14 days), grower (15-28 days), and finisher (29-42 days) phases. In each trial, five hundred and sixty male Cobb $500^{\circledR}$ broilers were randomly assigned into seven treatments with four replicates of 20 birds. The treatments consisted of seven levels of digestible SAA or Thr.

\section{Experimental diets}

The experimental diets were formulated using the dilution technique (Fisher and Morris, 1970). The procedure consisted of formulating two diets: a summit diet with high nitrogen content, and a nitrogen-free diet (Table 1).

The summit diet was formulated to contain approximately 1.2 times the requirement of SAA or Thr suggested by Rostagno et al. (2011) for broilers during the respective phases. All the other essential amino acids were set at a minimum of 1.4 times their suggested levels. 
The diets contained the same levels of energy, minerals, and vitamins recommended by Rostagno et al. (2011). Sulfur amino acid levels obtained from graded dilution of the summit and nitrogen-free diets ranged from 0.253 to $0.904 \%, 0.226$ to $0.814 \%$, and
0.208 to $0.750 \%$ for the starter, grower, and finisher phases, respectively. In the Thr assay, the levels studied ranged from 0.150 to $0.999 \%$ in the starter phase, 0.130 to $0.889 \%$ in the grower phase, and 0.120 to $0.819 \%$ in the finisher phase.

Table 1. Composition (\%) of summit and nitrogen-free diets.

\begin{tabular}{|c|c|c|c|}
\hline \multirow{2}{*}{ Ingredients } & \multicolumn{2}{|c|}{ Summit Diets } & \multirow{2}{*}{ Nitrogen-free diet } \\
\hline & Methionine+cystine & Threonine & \\
\hline Soybean Meal & 51.000 & 51.000 & - \\
\hline Corn & 33.900 & 33.900 & - \\
\hline Corn Gluten $60 \%$ & 3.710 & 3.742 & - \\
\hline Soybean Oil & 6.500 & 6.500 & 10.000 \\
\hline Dicalcium Phosphate & 2.030 & 2.030 & 2.703 \\
\hline Limestone & 0.945 & 0.945 & 0.507 \\
\hline Salt & 0.438 & 0.438 & 0.513 \\
\hline Choline Chloride (60\%) & 0.100 & 0.100 & 0.100 \\
\hline Mineral and Vitamin supplement ${ }^{l}$ & 0.100 & 0.100 & 0.100 \\
\hline DL-Methionine (99\%) & 0.328 & 0.512 & - \\
\hline L-Lysine $\mathrm{HCl}(78.5 \%)$ & 0.489 & 0.487 & - \\
\hline L-Threonine (99\%) & 0.201 & 0.033 & - \\
\hline L-Valine $(99 \%)$ & 0.140 & 0.140 & - \\
\hline L-Arginine (98.5\%) & 0.054 & 0.053 & - \\
\hline Potassium Chloride & - & - & 1.140 \\
\hline Starch + Sugar + Inert $^{2}$ & - & - & 84.872 \\
\hline Additive $^{3}$ & 0.065 & 0.065 & 0.065 \\
\hline \multicolumn{4}{|l|}{ Nutritional composition: } \\
\hline Metabolizable energy $(\mathrm{kcal} / \mathrm{kg})^{4}$ & 3,100 & 3,100 & 3,100 \\
\hline Crude protein 5 & 29.400 & 29.800 & 0.890 \\
\hline Methionine + cysteine ${ }^{5}$ & 0.840 & 1.080 & - \\
\hline Cystine $^{5}$ & 0.258 & 0.332 & - \\
\hline Methionine $^{5}$ & 0.582 & 0.748 & - \\
\hline Lysine $^{5}$ & 1.680 & 1.710 & - \\
\hline Threonine $^{5}$ & 1.020 & 0.793 & - \\
\hline Calcium $^{4}$ & 1.000 & 1.000 & 1.000 \\
\hline Sodium ${ }^{4}$ & 0.220 & 0.220 & 0.220 \\
\hline Available phosphorus ${ }^{4}$ & 0.500 & 0.500 & 0.500 \\
\hline
\end{tabular}

${ }^{I}$ Content $/ \mathrm{kg}$ of product: $\mathrm{Mn}=150,000 \mathrm{mg} . \mathrm{Fe}=100,000 \mathrm{mg} . \mathrm{Zn}=100,000 \mathrm{mg} . \mathrm{Cu}=16,000 \mathrm{mg}$. I = 1,500 mg. Folic acid $=1,000$ mg. Pantothenic acid $=15,000 \mathrm{mg}$. Niacin $=40,000 \mathrm{mg}$. Biotin $=60 \mathrm{mg}$. Vit. B1 $=1,800 \mathrm{mg}$. Vit. B12=12,000 mg. Vit. B2= $6,000 \mathrm{mg}$. Vit. B6 =2,800 mg. Vit. D3 =2,000 IU. Vit. E =15,000 mg. Vit. K3=1,800 mg. Se=300 mg.

${ }^{2}$ Corn Starch (42.796\%), Sugar (15\%), Rice Husk (15\%), and Washed Sand (12.076\%).

${ }^{3}$ Salinomycin Sodium $12 \%(0.05 \%)$, Avilamycin (0.005\%), Antioxidant $(0.01 \%)$.

${ }^{4}$ Calculated.

${ }^{5}$ Analyzed. 


\section{Management and data collection}

In each trial, before assigning chicks to dietary treatments, all birds were individually weighed to guarantee homogeneous initial body weights among treatments and were randomly distributed in the experimental units. At the beginning of grower and finisher phases, birds were replaced by chicks raised separately until the 14th and 28th days of age, respectively. This practice avoided residual effects of treatments and, throughout this period, chicks were fed diets formulated to meet or exceed the nutritional recommendations of Brazilian Tables for Poultry and Swine (Rostagno et al., 2011). Broilers were raised in an environmentally controlled facility, in which temperature and humidity were set according to genetic guideline recommendations. Photoperiod was set daily at $24 \mathrm{~L}$. All pens were equipped with hanging feeders and nipple drinkers, which provided free access to water and feed (mash form) throughout the entire experimental period. The birds and the remaining feed were weighed at the end of each phase in each experiment to determine the mean body weight (BW) and feed intake (FI). Bodyweight gain (BWG) and feed conversion ratio were also calculated. Mortality was recorded daily to adjust FI and hence FCR.

\section{Fitting the segmented models}

To evaluate broiler response and proceed with the economic analysis, data was fitted to a quadratic model with a plateau (Robbins et al., 2006). This model consists of two segments that connect in a smooth manner. Therefore, for values of $\boldsymbol{x}$ less than $\boldsymbol{x}_{\boldsymbol{v}}$, the mean of $Y$ is a quadratic function in $x$. On the other hand, for values of $x$ greater than $x_{0}$, the mean of $Y$ is constant, as follows:

$$
[Y|x|]=\left\{\begin{array}{cc}
\alpha+\beta x+\gamma x^{2} & \text { if } x<x_{0} \\
c & \text { if } x \geq x_{0}
\end{array}\right.
$$

where $\alpha, \beta$, and $\gamma$ are the coefficients of the quadratic segment and $c$ is the plateau of the function. The NLIN procedure was used to fit the segmented model and to determine the join point $\left(\boldsymbol{x}_{\boldsymbol{\theta}}\right)$ between the quadratic function and plateau. Moreover, conditions on the two segments of the model were imposed:

1) The curve should be continuous, i.e., the quadratic and the plateau section need to meet at $\boldsymbol{x}_{\boldsymbol{0}}$ :

$$
\left[\mathrm{Y}\left|\mathrm{x}_{0}\right|\right]=\alpha+\beta \mathrm{x}_{0}+\gamma \mathrm{x}_{0}^{2}
$$

2) The curve should be smooth, i.e., the first derivative of the two segments with respect to $\boldsymbol{x}$ need to coincide at $\boldsymbol{x}_{\boldsymbol{\theta}}$ :

$$
\frac{\mathrm{d}\left[\mathrm{Y}\left|\mathrm{x}_{0}\right|\right]}{\mathrm{dx}}=\beta+2 \gamma x_{0}=0
$$

Solving $\boldsymbol{x}_{\boldsymbol{0}}$ and substituting into the expression for $c(\mathrm{c}=\alpha+\beta \mathrm{x} 0+\gamma \mathrm{x} 02)$, the two conditions jointly imply that $x_{0}=-\beta / 2 \gamma$ and $\mathrm{c}=\alpha-\beta 2 / 4 \gamma$. Thus, the PROC NLIN was used to fit this segmented model and obtain these coefficients for body weight gain (BWG) and feed intake (FI).

Determination of the optimal methionine and threonine level through economic approach

The procedures adopted to estimate the optimal economic SAA and Thr levels are described as follows. Initially, variation of feed price $(\triangle \mathrm{FP})(\mathrm{USD} \$ / \mathrm{kg})$ was calculated in response to increasing dietary digestible SAA or Thr levels, as follows:

$$
\Delta \mathrm{FP}=[\mathrm{PBD}+(\mathrm{CAAS}-\mathrm{ICAABD}) \times \mathrm{PAA}] / 100,
$$

where PBD is price per $\mathrm{kg}$ of the basal diet without the addition of DL-methionine or L-threonine (USD $\$ / \mathrm{kg}$ ); CAAS is the concentration of the amino acid in diet after its supplementation in crystalline form (\%); ICAABD is the initial concentration of the amino acid in the basal diet (\%), and PAA is the price of DL-methionine or L-threonine per $\mathrm{kg}$ (USD \$ $/ \mathrm{kg}$ ). Then, total feed costs (TFC) were calculated for each level of amino acid supplementation by multiplying daily feed intake $(\mathrm{g})$ estimated in the segmented model 
by feed price variation $(\triangle \mathrm{FP})$ in the interval tested for each amino acid. Gross income (GI) was obtained by multiplying total body weight gain (daily BWG $x$ number of days of the assay) estimated using the segmented model by the selling price of live broilers (USD \$ $/ \mathrm{kg}$ ). Based on feedstuff prices in Brazil, the price of basal diets used were calculated for starter, grower and finisher phases as 0.56, 0.55, and USD $\$ 0.52 / \mathrm{kg}$, respectively, whereas the selling price of live broiler weight was assumed at USD $\$ 1.40 / \mathrm{kg}$. The current prices of crystalline Met and Thr were considered as USD $\$ 3.00 / \mathrm{kg}$. The gross margin obtained per bird (USD \$/bird) was calculated for each supplementation level of either Met or Thr, as follows:

$$
\mathrm{GM}=\mathrm{GI}-\mathrm{TFC},
$$

where GM is the gross margin obtained per bird (USD \$/bird); GI is the gross income (USD \$/bird), and TFC is the total feed cost per bird (USD \$/bird). In each phase, the optimal levels of digestible SAA and Thr in diets were obtained based on economic analysis, i.e., the optimal amino acid level was obtained when the amplitude between GI and TFC reached the greatest value, resulting in the maximum gross margin $\left(\mathrm{GM}_{\max }\right)$. After this point, each supplementation level above the optimal would increase total feed costs, reducing the gross margin.

Statistical analyzes were performed using the computer program SAS, version 9.3 , by means of GLM procedures for variance analysis and NLIN (Gauss-Newton) to adjust the segmented models (SAS, 2011).

\section{Results}

\section{Growth performance}

Graded SAA concentration in diets elicited a response in broiler FI and BWG regardless of the phases assessed $(p<0.01)$. Broilers in the starter phase exhibited maximum FI $(35.67 \mathrm{~g} /$ bird/d) and maximum BWG (30.04 g/bird/d) at 0.410 and $0.630 \%$ of $\mathrm{SAA}$, respectively (Table 2). In the grower phase, FI achieved the highest value of $85.41 \mathrm{~g} / \mathrm{bird} / \mathrm{d}$ and maximum BWG was $63.42 \mathrm{~g} / \mathrm{bird} / \mathrm{d}$ when dietary Thr was provided at 0.380 and $0.590 \%$, respectively. In the finisher phase, the amount of SAA in diets of $0.380 \%$ supported a maximum FI of $187.42 \mathrm{~g} /$ bird/d, whereas the level of these amino acids, which maximized BWG in $104.58 \mathrm{~g} / \mathrm{bird} / \mathrm{d}$ was $0.520 \%$. In all the phases assessed, the estimated breakpoints for BWG were higher than those estimated for FI; i.e., at some point, BWG continually grew when FI had already achieved the response plateau. Therefore, assuming that broiler FI theoretically remained the same after the breakpoint, we estimated the optimal SAA intake $(\mathrm{mg} / \mathrm{bird} / \mathrm{d})$ for BWG by multiplying the maximum FI estimated in each phase by the SAA level (\%) which optimized BWG. Therefore, optimal daily SAA intake for BWG in the starter, grower, and finisher phases were 225, 504, and $975 \mathrm{mg} / \mathrm{bird} / \mathrm{d}$, respectively.

As SAA, graded levels of digestible Thr influenced $(p<0.01)$ broiler BWG and FI regardless of the phase evaluated (Tables 2 and 3 ).

For broilers in the starter phase, the quadratic broken-line model estimated maximum FI (30.10 $\mathrm{g} / \mathrm{bird} / \mathrm{d}$ ) at $0.520 \%$ of Thr, and maximum BWG $(21.78 \mathrm{~g} / \mathrm{bird} / \mathrm{d})$ at $0.790 \%$. In the grower phase the highest values of FI (105.53 $\mathrm{g} / \mathrm{bird} / \mathrm{d})$ and BWG $(66.79 \mathrm{~g} / \mathrm{bird} / \mathrm{d})$ were achieved at 0.460 and $0.660 \%$ of $\mathrm{Thr}$, respectively. In the finisher phase, the Thr levels, which maximized FI in $179.63 \mathrm{~g} / \mathrm{bird} / \mathrm{d}$ and BWG in $105.39 \mathrm{~g} / \mathrm{bird} / \mathrm{d}$, were 0.410 and $0.580 \%$, respectively. Following the same procedures adopted in SAA assays, we estimated the optimal Thr intake for BWG in the starter, grower, and finisher phases in 236, 696, $1,042 \mathrm{mg} / \mathrm{bird} / \mathrm{d}$, respectively. From a statistical point of view, the segmented models were adequate to describe broiler responses in function of increasing dietary digestible SAA and Thr levels in all phases (Table 4). 
Table 2. Summarized results for body weight gain (BWG) and feed intake (FI) of male broilers in response to methionine+cystine (SAA) intake during three phases (means $\pm \mathrm{SD}$ ).

\begin{tabular}{|c|c|c|c|c|}
\hline Diets & $\begin{array}{c}\text { SAA levels } \\
\text { (\%) }\end{array}$ & $\begin{array}{l}\text { SAA intake } \\
\text { (mg/d) }\end{array}$ & $\begin{array}{c}\text { FI } \\
(g / d)\end{array}$ & $\begin{array}{l}\text { BWG } \\
(g / d)\end{array}$ \\
\hline \multicolumn{5}{|c|}{ Initial phase (1-14 d) } \\
\hline D1 & 0.253 & $58.96 \pm 3.80$ & $23.58 \pm 1.52$ & $10.71 \pm 0.78$ \\
\hline D2 & 0.362 & $123.75 \pm 4.92$ & $34.38 \pm 1.37$ & $20.87 \pm 0.68$ \\
\hline D3 & 0.470 & $171.19 \pm 3.02$ & $36.42 \pm 0.64$ & $26.46 \pm 0.39$ \\
\hline D4 & 0.579 & $214.46 \pm 1.08$ & $36.98 \pm 0.19$ & $29.31 \pm 0.29$ \\
\hline D5 & 0.687 & $249.42 \pm 3.25$ & $36.15 \pm 0.47$ & $30.66 \pm 0.67$ \\
\hline D6 & 0.796 & $283.38 \pm 5.19$ & $35.42 \pm 0.65$ & $30.78 \pm 0.79$ \\
\hline D7 & 0.904 & $300.38 \pm 7.76$ & $33.38 \pm 0.86$ & $29.03 \pm 0.84$ \\
\hline $\mathrm{p}$-value & & $<0.001$ & $<0.001$ & $<0.001$ \\
\hline \multicolumn{5}{|c|}{ Grower phase (15-28 d) } \\
\hline D1 & 0.226 & $174.00 \pm 4.60$ & $76.99 \pm 2.03$ & $30.45 \pm 1.08$ \\
\hline D2 & 0.325 & $274.74 \pm 8.10$ & $84.42 \pm 2.49$ & $46.48 \pm 1.97$ \\
\hline D3 & 0.425 & $368.17 \pm 5.78$ & $86.65 \pm 1.36$ & $56.13 \pm 1.80$ \\
\hline D4 & 0.524 & $445.88 \pm 1.37$ & $85.04 \pm 0.26$ & $62.47 \pm 0.48$ \\
\hline D5 & 0.615 & $536.60 \pm 4.50$ & $87.29 \pm 0.73$ & $61.99 \pm 1.03$ \\
\hline D6 & 0.714 & $611.42 \pm 7.83$ & $85.61 \pm 1.10$ & $65.12 \pm 1.26$ \\
\hline D7 & 0.814 & $670.76 \pm 10.08$ & $82.44 \pm 1.24$ & $63.08 \pm 4.08$ \\
\hline $\mathrm{p}$-value & & $<0.001$ & $<0.001$ & $<0.001$ \\
\hline \multicolumn{5}{|c|}{ Finisher phase (29-42 d) } \\
\hline D1 & 0.208 & $348.54 \pm 7.27$ & $167.63 \pm 3.49$ & $59.79 \pm 2.04$ \\
\hline D2 & 0.298 & $546.46 \pm 6.79$ & $183.18 \pm 2.27$ & $83.93 \pm 2.19$ \\
\hline D3 & 0.389 & $730.74 \pm 13.00$ & $187.99 \pm 3.35$ & $96.96 \pm 1.71$ \\
\hline D4 & 0.479 & $913.13 \pm 2.05$ & $190.58 \pm 0.43$ & $100.68 \pm 4.08$ \\
\hline D5 & 0.570 & $1077.77 \pm 14.98$ & $189.24 \pm 2.63$ & $103.71 \pm 2.15$ \\
\hline D6 & 0.660 & $1235.62 \pm 2.60$ & $187.24 \pm 0.39$ & $107.50 \pm 1.81$ \\
\hline D7 & 0.750 & $1372.61 \pm 22.61$ & $182.94 \pm 3.01$ & $105.09 \pm 5.72$ \\
\hline $\mathrm{p}$-value & & $<0.001$ & $<0.001$ & $<0.001$ \\
\hline
\end{tabular}


Table 3. Summarized results for body weight gain (BWG) and feed intake (FI) of male broilers in response to threonine (Thr) intake during three phases (means $\pm \mathrm{SD}$ ).

\begin{tabular}{|c|c|c|c|c|}
\hline Diets & $\begin{array}{c}\text { Thr levels } \\
\text { (\%) }\end{array}$ & $\begin{array}{c}\text { Thr intake } \\
\text { (mg/d) }\end{array}$ & $\begin{array}{c}\text { FI } \\
(\mathrm{g} / \mathrm{d})\end{array}$ & $\begin{array}{l}\text { BWG } \\
(\mathrm{g} / \mathrm{d})\end{array}$ \\
\hline \multicolumn{5}{|c|}{ Initial phase (1-14 d) } \\
\hline D1 & 0.150 & $17.95 \pm 1.31$ & $11.98 \pm 0.87$ & $2.85 \pm 0.17$ \\
\hline D2 & 0.400 & $112.60 \pm 11.84$ & $28.17 \pm 2.96$ & $14.53 \pm 1.69$ \\
\hline D3 & 0.520 & $158.59 \pm 2.89$ & $30.52 \pm 0.56$ & $18.26 \pm 0.77$ \\
\hline D4 & 0.640 & $202.72 \pm 6.20$ & $31.70 \pm 0.97$ & $21.54 \pm 1.19$ \\
\hline D5 & 0.759 & $220.38 \pm 6.88$ & $29.02 \pm 0.91$ & $20.55 \pm 0.71$ \\
\hline D6 & 0.879 & $265.13 \pm 16.44$ & $30.15 \pm 1.87$ & $22.30 \pm 1.44$ \\
\hline D7 & 0.999 & $291.17 \pm 16.64$ & $29.14 \pm 1.67$ & $21.97 \pm 1.54$ \\
\hline $\mathrm{p}$-value & & $<0.001$ & $<0.001$ & $<0.001$ \\
\hline \multicolumn{5}{|c|}{ Grower phase (15-28 d) } \\
\hline D1 & 0.130 & $103.02 \pm 2.79$ & $79.30 \pm 2.14$ & $13.34 \pm 0.26$ \\
\hline D2 & 0.350 & $444.19 \pm 16.07$ & $127.00 \pm 4.59$ & $48.84 \pm 2.15$ \\
\hline D3 & 0.460 & $521.72 \pm 13.14$ & $113.50 \pm 2.86$ & $59.60 \pm 1.45$ \\
\hline D4 & 0.570 & $626.48 \pm 28.76$ & $109.99 \pm 5.04$ & $64.72 \pm 3.22$ \\
\hline D5 & 0.670 & $706.38 \pm 11.00$ & $105.50 \pm 1.64$ & $67.50 \pm 1.52$ \\
\hline D6 & 0.779 & $803.26 \pm 9.93$ & $103.05 \pm 1.27$ & $68.32 \pm 1.58$ \\
\hline D7 & 0.889 & $850.31 \pm 9.26$ & $95.61 \pm 1.04$ & $64.73 \pm 0.99$ \\
\hline p-value & & $<0.001$ & $<0.001$ & $<0.001$ \\
\hline \multicolumn{5}{|c|}{ Finisher phase (29-42 d) } \\
\hline D1 & 0.120 & $188.62 \pm 3.73$ & $157.29 \pm 3.10$ & $28.73 \pm 2.87$ \\
\hline D2 & 0.330 & $666.43 \pm 13.26$ & $202.11 \pm 4.02$ & $84.15 \pm 2.92$ \\
\hline D3 & 0.420 & $848.26 \pm 27.70$ & $202.09 \pm 6.60$ & $95.71 \pm 2.88$ \\
\hline D4 & 0.520 & $964.44 \pm 25.60$ & $185.60 \pm 4.92$ & $100.98 \pm 2.87$ \\
\hline D5 & 0.620 & $1111.70 \pm 13.11$ & $179.43 \pm 2.11$ & $107.67 \pm 1.34$ \\
\hline D6 & 0.719 & $1260.66 \pm 54.46$ & $175.21 \pm 7.56$ & $107.84 \pm 6.13$ \\
\hline D7 & 0.819 & $1358.75 \pm 44.59$ & $165.82 \pm 5.44$ & $102.62 \pm 4.88$ \\
\hline $\mathrm{p}$-value & & $<0.001$ & $<0.001$ & $<0.001$ \\
\hline
\end{tabular}


Table 4. Parameter adjusted in the segmented model using the performance data obtained in dose-response studies with broilers receiving diets limiting in methionine+cystine and threonine.

\begin{tabular}{|c|c|c|c|c|c|c|c|c|c|}
\hline Amino acid & Phase & Variable & \multicolumn{5}{|c|}{ Parameters of the segmented model ${ }^{l}$} & \multicolumn{2}{|c|}{ Statistic } \\
\hline \multirow{7}{*}{ Methionine+cystine } & \multirow{3}{*}{$\begin{array}{l}\text { Initial } \\
(1-14 d)\end{array}$} & & $\alpha$ & $\beta$ & $\gamma$ & $\mathrm{x}_{0}$ & $\mathrm{c}$ & $\mathrm{R}^{2}$ & p-value \\
\hline & & Feed intake & $-41.65 \pm 14.02$ & $374.00 \pm 27.56$ & $-452.20 \pm 30.60$ & 0.41 & 35.67 & 0.97 & $<0.0001$ \\
\hline & & Weight Gain & $-22.67 \pm 2.32$ & $167.60 \pm 11.10$ & $-133.20 \pm 12.11$ & 0.63 & 30.04 & 0.99 & $<0.0001$ \\
\hline & Grower & Feed intake & $32.32 \pm 19.52$ & $277.80 \pm 32.00$ & $-363.50 \pm 23.20$ & 0.38 & 85.41 & 0.86 & $<0.0001$ \\
\hline & & Weight Gain & $-26.05 \pm 5.22$ & $305.80 \pm 26.76$ & $-261.20 \pm 31.42$ & 0.59 & 63.42 & 0.98 & $<0.0001$ \\
\hline & Finisher & Feed intake & $86.99 \pm 23.18$ & $531.90 \pm 63.20$ & $-704.40 \pm 72.10$ & 0.38 & 187.42 & 0.92 & $<0.0001$ \\
\hline & $(29-42 d)$ & Weight Gain & $-21.08 \pm 10.09$ & $487.20 \pm 58.85$ & $-472.30 \pm 78.09$ & 0.52 & 104.58 & 0.97 & $<0.0001$ \\
\hline \multirow{7}{*}{ Threonine } & \multirow{3}{*}{$\begin{array}{c}\text { Initial } \\
(1-14 d)\end{array}$} & & $\alpha$ & $\beta$ & $\gamma$ & $\mathrm{x}_{0}$ & $\mathrm{c}$ & $\mathrm{R}^{2}$ & $\mathrm{p}$-value \\
\hline & & Feed intake & $-5.65 \pm 2.97$ & $137.20 \pm 21.31$ & $-131.70 \pm 30.94$ & 0.52 & 30.10 & 0.95 & $<0.0001$ \\
\hline & & Weight Gain & $-7.19 \pm 1.23$ & $73.46 \pm 5.62$ & $-46.57 \pm 5.61$ & 0.79 & 21.78 & 0.97 & $<0.0001$ \\
\hline & \multirow{2}{*}{$\begin{array}{c}\text { Grower } \\
(15-28 d)\end{array}$} & Feed intake & $48.02 \pm 12.45$ & $252.00 \pm 62.10$ & $-276.10 \pm 79.00$ & 0.46 & 105.53 & 0.95 & $<0.0001$ \\
\hline & & Weight Gain & $-15.74 \pm 2.30$ & $249.20 \pm 12.09$ & $-188.10 \pm 14.06$ & 0.66 & 66.79 & 0.99 & $<0.0001$ \\
\hline & \multirow{2}{*}{$\begin{array}{l}\text { Finisher } \\
(29-42 d)\end{array}$} & Feed intake & $115.20 \pm 10.91$ & $312.70 \pm 80.90$ & $-379.60 \pm 86.20$ & 0.41 & 179.63 & 0.87 & $<0.0001$ \\
\hline & & Weight Gain & $-15.47 \pm 4.18$ & $414.20 \pm 25.76$ & $-354.80 \pm 34.41$ & 0.58 & 105.39 & 0.98 & $<0.0001$ \\
\hline
\end{tabular}

${ }^{I} \alpha, \beta$, and $\gamma$ are the coefficients of the quadratic segment; $\mathrm{x}_{0}$ is the join point; $\mathrm{c}$ is the plateau of the function; and $\mathrm{R}^{2}$ is the coefficient of determination.

\section{Economic analysis}

Sulfur amino acids. The GI values calculated for the starter, grower, and finisher phases were $0.589,1.244$, and USD 2.049/bird, respectively. Total feed cost was calculated as $0.285,0.670$, and USD 1.412/bird for the starter, grower, and finisher phases, respectively. Hence, the gross margin(GI-TFC) calculated for the starter, grower, and finisher phases were 0.304 (Fig. 1A), 0.573 (Fig. 1B), and USD 0.638 (Fig. 1C), respectively.
Threonine. The calculated gross income for the starter, grower, and finisher phases were $0.427,1.309$, and USD 2.066/bird, respectively. The values obtained for TFC were $0.244,0.836$, and USD 1.342/bird for the starter, grower, and finisher phases, respectively. Based on these values, the gross margin (GI-TFC) for starter, grower, and finisher phases were calculated as USD 0.183 (Fig. 2A), USD \$0.473 (Fig. 2B), and USD 0.724 (Fig. 2C), respectively. 


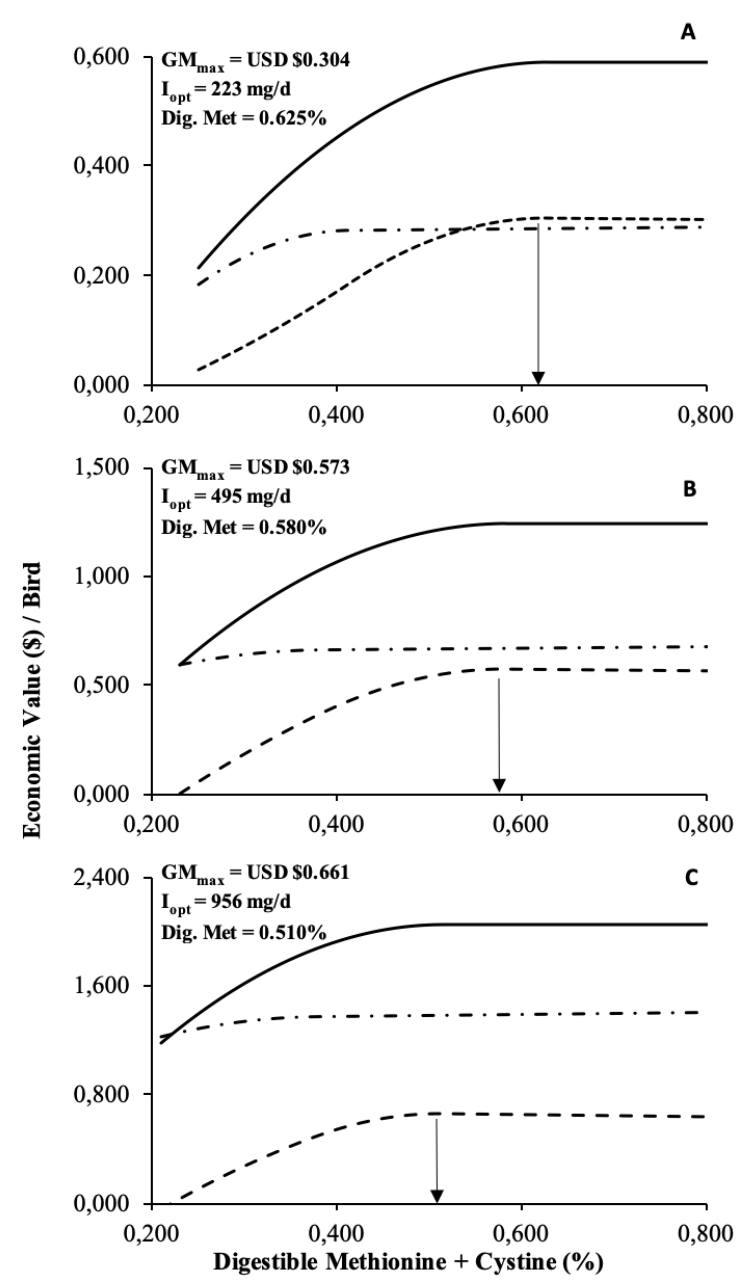

Figure 1. Maximum gross margins (GMmax), optimal digestible methionine + cystine, intake (Iopt), and concentration (Dig. Met+Cys) of broiler chickens raised from 1 to 14 (A), 15 to 28 (B) and 29 to 42 (C) days old. Gross income (-), Feed costs (--), and Gross margins (---).

\section{Discussion}

Rather than using an exponential model to estimate the optimal economic SAA and Thr levels for broilers, this study opted for a segmented model (polynomial quadratic with plateau) to fulfill such purpose. We believe that extrapolating unknown points outside the control point distribution space may increase errors, which in turn, may not represent properly the biological processes, as observed by Kratzer and Littell (2006). Our results showed that the optimal economic amino acid intake coincides with the optimal amino acid
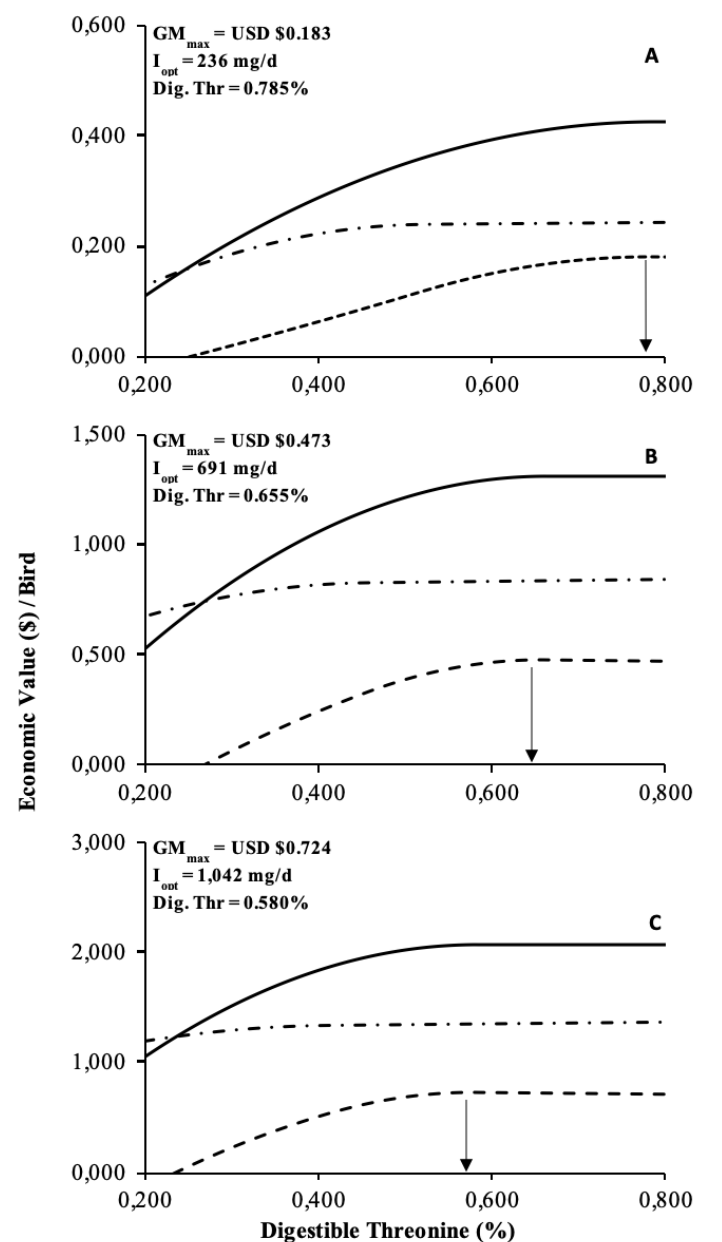

Figure 2. Maximum gross margins (GMmax), optimal threonine intake (Iopt), and concentration (Dig. Thr) for broiler chickens raised from 1 to 14 (A), 15 to 28 (B) and 29 to 42 (C) days old. Gross income (--), Feed costs (-), and Gross margins (---).

intake for optimal weight gain, which leads to conclude that, in this case, weight gain is the determinant factor in defining the optimal level that maximizes profit. Similarly, Kidd et al. (1999) noted that the optimal Thr level for best profitability was close to that which maximized broiler performance.

Regarding the optimal $\mathrm{Thr}$ level for performance for the starter phase, Barkley and Wallis (2001) reported that $7.2 \mathrm{~g} \mathrm{Thr} / \mathrm{kg}$ diet maximized broiler BW from 7 to $21 \mathrm{~d}$ of age. This value was lower in the present study, but it was expected due to the modeling and the 
procedures used to estimate body composition. For the grower phase, Rangel-Lugo et al. (1994) estimated that $6.3 \mathrm{~g} / \mathrm{kg}$ of diet could be used to maximize weight gain in broilers from 16 to 28 $\mathrm{d}$, which is close to the amount of Thr found herein $(6.6 \mathrm{~g} / \mathrm{kg}$ of diet). After performing economic analysis, Kidd et al. (1999) suggested that meeting the minimum dietary amount of Thr for broilers in the finisher phase (about $0.60 \%$ digestible Thr in the diet) is necessary to optimize profitability. This value is not too far from the digestible $\mathrm{Thr}$ recommendation found herein, which was $0.580 \%$.

Ohta and Ishibashi (1994) suggested that $0.66 \%$ of SAA is required for maximum broiler growth performance from 8 to 18 days of age, which is slightly higher than the $0.630 \%$ estimated in our study. Lumpkins et al. (2007) also found a similar SAA requirement for BWG $(0.67 \%)$ in the starter phase ( 0 to 3 weeks of age). At the grower period (21-42 d), the same authors found the requirements for SAA as $0.55 \%$ to maximize $\mathrm{BWG}$, which is close to the values observed here $(0.590 \%$ in the grower phase, and $0.520 \%$ in the finisher phase). On the other hand, Goulart et al. (2011) reported the optimal SAA levels of $0.873,0.755,0.748$, and $0.661 \%$ for Cobb male broilers in the prestarter (1-7d), starter (8-21d), grower (22-35d) and finisher (36-42d) phases, respectively.

Pack and Schutte (1995) suggested a dietary level of $0.95 \%$ SAA as the most profitable level for broilers grown to $1.7 \mathrm{~kg}$ under European price conditions, which is higher in comparison with the recommendations based on the given price conditions of the current study. The optimal intake observed for dietary $\mathrm{Thr}$ to optimize BWG or GM are not too different from those reported in the literature, even when different models were used.

However, the same behavior was not observed for SAA levels recommended in the literature, where higher values are often described. The optimal intake for SAA found in the current study was similar to Lumpkins et al. (2007), who used a broken-line model with one slope that is known by underestimating the nutrient requirements. On the other hand, the segmented model used for fitting the performance data estimated the optimal level in the highest point as in the polynomial quadratic model. However, the values were lower than those predicted by Goulart et al. (2011) using the quadratic model. A possible explanation may rely on the difference among birds on dietary SAA utilization for gain, which resulted in lower levels of SAA required than in those studies.

Considering the prices of L-threonine and DL-methionine as USD $\$ 3.00 / \mathrm{kg}$, the optimal SAA levels to improve GM were 225, 504, and $975 \mathrm{mg} / \mathrm{d}$. In contrast, for Thr these values were 236, 696, and $1042 \mathrm{mg} / \mathrm{d}$ for the starter, grower and finisher phases, respectively. When both crystalline amino acid prices doubled to USD $\$ 6.00 / \mathrm{kg}$, the optimal SAA intakes switched to 222,494 , and $946 \mathrm{mg} / \mathrm{d}$ and $\mathrm{Thr}$ intakes to 233, 686, and 1,033 mg/d in starter, grower and finisher phases, respectively. Regarding different economic scenarios (changing prices of feed and selling price), the optimal economic intake of dietary SAA and Thr were slightly affected. The DL-methionine and L-threonine are the feed ingredients with highest impact on economic return; such observation was also reported by Pack and Schutte (1995). The increase in the crystalline amino acid price from USD 3.00 to 6.00 decreased the maximum GM by $1.89,2.24$, and $3.70 \%$ for SAA and by $4.54,5.15$, and $4.99 \%$ for $\mathrm{Thr}$ within the starter, grower and finisher phases, respectively. The increase of the DL-methionine price caused a lower variation in the gross margin than the Thr price increase. This is because broilers are 3less efficient in using dietary $\mathrm{Thr}$, since they need more feed to achieve a lower value of BWG when compared to birds fed a diet containing crescent levels of SAA. Therefore, to achieve the optimum economic return, the efficiency of nutrient utilization should be taken into account.

Even though our simulations provide an idea about the behavior of feed cost in response to changes in the price of inputs (feedstuffs) and outputs (live broiler BW), a complete 
economic analysis should include all the variable and/or fix costs in poultry production. Nevertheless, feed costs represent about 65 to $70 \%$ of total poultry production, thus, improving the economic return related to feed cost is an essential step toward maximum profit. For example, the TFC in the finisher phase resulted in USD 1.412/bird for broilers fed SAA. However, one may assume the existence of $30 \%$ more costs, aiming to estimate a total production cost, in this case resulting in USD $1.836 /$ bird. Discounting this value from GI of USD $2.049 /$ bird, net profit will result in approximately USD 0.213 per bird.

In conclusion, variations on the crystalline amino acid prices slightly affected the optimal economic intake of total sulfur amino acid and Thr. Therefore, considering the cost of DLmethionine and L-threonine at USD \$ 3.00/ $\mathrm{kg}$, the optimal total sulfur amino acid intakes to optimize GM was 223, 504 and $975 \mathrm{mg} /$ $\mathrm{bird} / \mathrm{d}$, and 236, 696, and 1,042 mg/bird/d for Thr in starter, grower and finisher phases, respectively.

\section{Declarations}

\section{Acknowledgments}

The authors gratefully acknowledge The Fundação de Amparo a Pesquisa do Estado de São Paulo - FAPESP (Brazil) for financial support (grant No. 2010/08972-3), and Ajinomoto Ltd. for donation of the crystalline amino acids and HPLC analysis.

\section{Funding}

This research was funded by Fundação de Amparo a Pesquisa do Estado de São Paulo FAPESP (Brazil) [grant number 2013/25761 $\square 4$ (N.K. Sakomura)].

\section{Author contribution}

Juliano C. Paula-Dorigam: conception of work, statistical analysis, data interpretation, writing of the paper, and final approval of the version to be published. Matheus De-Paula Reis: statistical analysis, data interpretation, reviewing of the manuscript, writing of the paper, final approval of the version to be published. Mirella CunhaMelaré: data interpretation, manuscript edition, reviewing of the manuscript, final approval of the version to be published. Gabriel Silva-Viana: data interpretation, manuscript edition, reviewing of the paper, final approval of the version to be published. Daniella C. Zanardo-Donato: design of the work, conduction of the experiments, collection, and interpretation of data reviewing of the paper. Nilva Kazue-Sakomura: administered the project, designed the study, reviewed the paper, and approved its final version.

\section{Conflict of interest}

The authors declare they have no conflicts of interest with regard to the work presented in this report.

\section{References}

Barkley GR, Wallis IR. Threonine requirements of broiler chickens: An experimental validation of a model using growth responses and carcase analysis. Br Poult Sci 2001; 42(5): 616-624. DOI: https://doi.org/10.1080/00071660120088434

Fisher C, Morris TR. The determination of the methionine requirements of laying pullets by a diet dilution technique. $\mathrm{Br}$ Poult Sci 1970; 11(1): 67-82. DOI: https://doi.org/10.1080/00071667008415793

Goulart CC, Costa FGP, Souza JHV, Rodrigues VP, Oliveira CLS. Requirements of digestible methionine+cystine for broiler chickens at 1 to 42 days of age. $\mathrm{R}$ Bras Zootec 2011; 40(4): 797-803. DOI: http://dx.doi.org/10.1590/S1516$\underline{35982011000400013}$

Hauschild L, Pomar C, Lovatto PA. Systematic comparison of the empirical and factorial methods used to estimate the nutrient requirements of growing pigs. Animal 2010; 4(5): 714-723. DOI: https://doi.org/10.1017/S1751731109991546 
Kidd MT, Lerner SP, Allard JP, Rao SK, Halley JT. Threonine needs of finishing broilers: growth, carcass, and economic responses. J Appl Poult Res 1999; 8(2): 160-169. DOI: https://doi.org/10.1093/japr/8.2.160

Kidd MT. Nutritional considerations concerning threonine in broilers. Worlds Poult Sci J 2000; 56 (2): 139-51. DOI: https://doi.org/10.1079/WPS20000011

Kidd MT, Corzo A, Hoehler D, Kerr BJ, Barber SJ, Branton SL. Threonine needs of broiler chickens with different growth rates. Poult Sci 2004; 83(8): 1368-1375. DOI: https://doi.org/10.1093/ps/83.8.1368

Kratzer DD, Littell RC. Appropriate statistical methods to comparedose responses ofmethionine sources. Poult Sci 2006; 85(5): 947-954. DOI: https://doi.org/10.1093/ps/85.5.947

Lumpkins BS, Batal AB, Baker DH. Variations in the digestible sulfur amino acid requirement of broiler chickens due to sex, growth criteria, rearing environment, and processing yield characteristics. Poult Sci 2007; 86(2): 325-330. DOI: https://doi.org/10.1093/ps/86.2.325

Ohta Y, Ishibashi T. Dietary levels and ratio of methionineand cystine formaximumperformance of broilers. Jpn Poult Sci 1994; 31(6): 369-380. DOI: https://doi.org/10.2141/jpsa.31.369

Pack M, Hoehler D, Lemme A. Economic assessment of amino acid responses in growing poultry. In: D'Mello JPF, editor. Amino acids in animal nutrition. 2nd ed. CABI Publishing 2003; 459-483.

Pack M, Schutte JB. Sulfur amino acid requirement of broiler chicks from fourteen to thirty-eight days of age. Economic evaluation. Poult Sci 1995; 74(3): 488-493. DOI: https://doi.org/10.3382/ps.0740488
Pesti GM, Vedenov D. An economic comparison of several models fitted to nutritional response data. J Anim Sci 2011; 89(10): 3344-3349. DOI: https://doi.org/10.2527/jas.2010-3459

Rangel-Lugo M, Su CL, Austic RE. Threonine requirement and threonine imbalance in broiler chickens. Poult Sci 1994; 73(5): 670-681. DOI: https://doi.org/10.3382/ps.0730670

Robbins KR, Saxton AM, Southern LL. Estimation of nutrient requirements using broken-line regression analysis. J Anim Sci 2006; 13 Suppl, 84:155-165. DOI: https://doi.org/10.2527/2006.8413 supplE155x

Rostagno HS, Albino LFT, Donzele JL, Gomes PC, Oliveira RF, Lopes DC, Ferreira AS, Barreto SLT, Euclides RF. Brazilian Tables for Poultry and Swine: Composition of Feedstuffs and Nutritional Requirements. 3rd ed.,Viçosa (MG): UFV publishing; 2011.

SAS Institute Inc. SAS ${ }^{\circledR} 9.3$ system options: reference. 2nd ed., Cary (NC): SAS Institute Inc.; 2011.

Siqueira JC, Sakomura NK, Dorigam JCP, Mendonça GG, Costa FGP, Fernandes JBK, Dourado LRB, Nascimento DCN. Lysine levels in diets of broilers determined based on economic approach. $\mathrm{R}$ Bras Zootec 2011; 40(10): 2178-2185. DOI: http://dx.doi.org/10.1590/S 1516 $\underline{35982011001000017}$

Vedenov D, Pesti GM. An economic analysis of a methionine source comparison response model. Poult Sci 2010; 89(11): 2514-2520. DOI: https://doi.org/10.3382/ps.2010-00640 